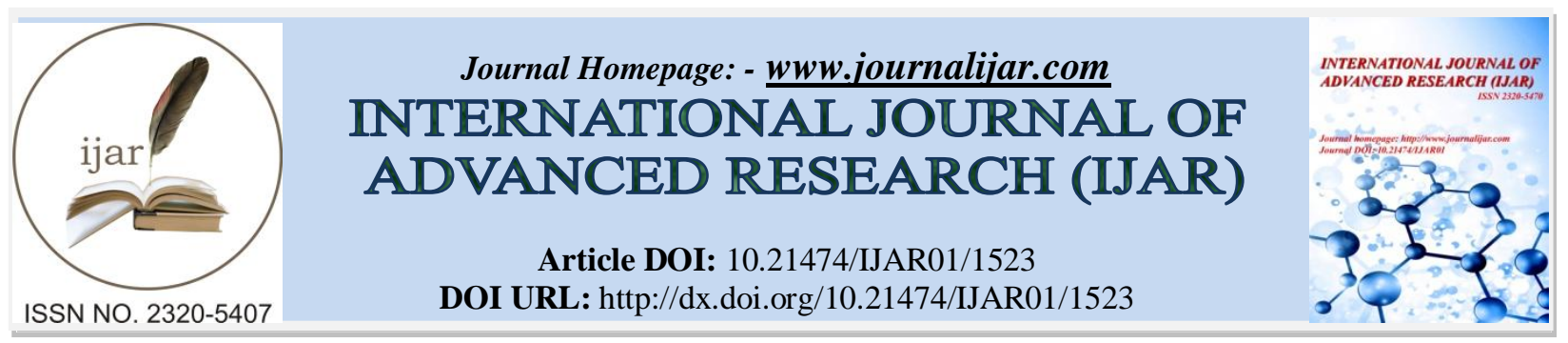

RESEARCH ARTICLE

\title{
INFLUENCE OF BANKING SECTOR LIQUIDITY ON FINANCIAL PERFORMANCE OF COMMERCIAL BANKS IN RWANDA
}

\section{Okello John Paul ${ }^{1}$, Gregory Namusonge ${ }^{2}$ and Kigabo Thomas ${ }^{3}$}

1. Lecturer and PhD student at Jomo Kenyatta University of Agriculture and Technology.

2. Lecturer at Jomo Kenyatta University of Agriculture and Technology.

3. Lecturer at Jomo Kenyatta University of Agriculture and Technology and Chief Economist BNR.

\section{Manuscript Info}

(n.........................

Manuscript History

Received: 12 July 2016

Final Accepted: 19 August 2016

Published: September 2016

\section{Abstract}

The link between banking development and economic growth has long received significant attention in research, however, the waves of banking development cannot raise the tide of the economy without affecting financial performance of commercial banks; it is against this background that this study was formulated with the objective of determining the influence of banking sector liquidity on financial performance of commercial banks in Rwanda. In this paper banking sector liquidity is proxied by Bank Deposits, Financial performance proxied by Return on Assets (ROA), Return on Equity (ROE) and Net Interest Margin (NIM) and both moderated by inflation proxied by consumer price index. This study was purely based on secondary data, multiple linear regression model was used to determine such influence between these two valuables. The study concluded that banking sector liquidity measured by bank deposits has a positive and significant influence on profitability measured by ROA and ROE but a negative significant influence on Cost of operation measured by NIM. It therefore means that banking sector liquidity influences profitability but does not influence the commercial banks cost of intermediation in Rwanda. For commercial banks in Rwanda to improve their profitability, they should put in place measures to encourage bank deposits for example higher interest rates to attract depositors. However to reduce the cost of intermediation, the study recommends that commercial banks in Rwanda need to reduce problem assets as high nonperforming loans dampen banks' potential lending capacity and, by extension, their ability to build up capital buffers. This study further recommends that commercial banks should do a lot of their own awareness, sensitization, education and training to increase the use of other financial innovations like ATM's, agency banking, internet banking and the use of credit cards to further promote mobilization of savings. 


\section{Introduction:-}

Commercial banks provide an intermediation service that brings savers and investors together, theoretically channeling investment funds to the uses that yield the highest rate of return, thus increasing specialization and the division of labor (Todaro, 2003). Risk is pooled, transferred, and reduced by commercial banks while liquidity and information increase through the use of progressively more sophisticated financial products and technology. Taking a look at the same from an aggregate production function point of view, each of these financial effects may contribute to the transformation of a given amount of savings and investment inputs into a larger amount of output through either a capital accumulation channel (Hicks, 1969)

Or a technological change channel, but only if there is financial stability (Schumpeter, 1912). These modern growth theories identify two specific channels through which the financial sector might affect long-run growth; through its impact on capital accumulation (including human as well as physical capital) and its impact on the rate of technological progress. These effects arise from the intermediation role provided by financial institutions which enable the financial sector to mobilise savings for investment, facilitate and encourage inflows of foreign capital (including FDI, portfolio investment and bonds, and remittances) and to optimize the allocation of capital between competing uses, ensuring that capital goes to its most productive use (Aburime, 2005).

It's important to stress that commercial banks play a vital role in the economic resource allocation of any country. This is because they channel funds from depositors to investors continuously. They can do so, if they generate necessary income to cover their operational cost they incur in the due course. In other words for sustainable intermediation function, banks need to be profitable. Beyond the intermediation function, the financial performance of banks has critical implications for economic growth of countries. Good financial performance rewards the shareholders for their investment. This, in turn, encourages additional investment and brings about economic growth. On the other hand, poor banking performance can lead to banking failure and crisis which have negative repercussions on the economic growth. Levine (1997) further identified five basic functions of financial intermediaries which summarize essence of banking development and give rise to these effects namely: Savings mobilization, risk management, acquiring information about investment opportunities, monitoring borrowers and exerting corporate control and facilitating the exchange of goods and services. Therefore a developed financial sector majorly with financial depth, financial liquidity and financially innovative may be the best tools for competition among commercial banks to achieve better financial performance (Sanya \& Gaertner 2012).

The capacity of Rwanda banks, especially commercial banks, is to accept deposits from the general public for the purport of lending and investment. This makes depositors the major stakeholders of the banking system. While sundry deposits products by banks are assigned different names for which they are designated to accommodate varying purposes, the deposit products of commercial banks can be broadly categorized into demand deposits, savings deposits, and term or fixed deposits. The Banks provide various services to sectors of the economy, for example liquidity services, information, maturity intermediation, transaction cost, credit allocation, payment services, and money supply services, among others (Elsevier, 2014).

The banking sector in Rwanda is expected to be even more vibrant in coming years. Deposits from individuals and private enterprises have been and continued to be contributing the largest share of bank's total deposits. Savings according to conventional economists is the excess income over consumption expenditure (Keynes, 1936). However a number of factors have been found to influence deposits of banks, especially commercial banks. In Malaysia, Haron and Azmi (2006) investigates the structural determinants of deposits level of commercial banks. The study found rates of profit, rates of interest, base lending rates, money supply, Consumer Price Index (CPI), Kuala Lumpur Composite Index, and Gross Domestic Product (GDP) to have significant impact on deposits. Commercial banks play vital role in the Rwanda as they aid individuals, and organizations (small, medium, or large) continue to meet their ever growing credit demands. For commercial banks to be able to meet this growing demand for credit by both micro and macro units (households and firms), it is however necessary to enhance the deposit rate or the willingness of the public to reduce the propensity to hold cash but still be able to have a better financial performance (Nishat $\&$ Bilgrami, 1989).

Therefore the main objective of this study is to determine the influence of banking sector liquidity on financial performance of commercial banks in Rwanda since 2010. Many studies earlier done in similar area have sought to establish the link between banking sector liquidity and economic growth and only a similar paper in Kenya by 
Andele (2013) sought to understand the influence of financial deepening and banks profitability in Kenyan commercial banks.

\section{Literature Review:-}

This section reviewed relevant literature and theories that touch on the dependent and independent variables were highlighted bellow, followed by the empirical review and the conceptual framework in that order.

\section{Reviewed Theories:- \\ The Life-Cycle Hypothesis of Savings.}

This model of savings, the life-cycle hypothesis was developed by Franco Modigliani and his student, Richard Brumberg in the early 1950s (Modigliani \& Brumberg, (1954). According to them, the rational individuals make their consumption decision based on the resources available to them over their life time, and also on their stages in the life cycle. Thus, the life-cycle hypothesis of savings, postulates that an individual's consumption in a particular period depend on their expectation about lifetime income so as to ensure a smooth consumption pattern over the lifetime. Further, the model predicts that in order to ensure a smooth level of consumption over time, by individual tend to save more in the early ages of life in order to provide for retirement. This theory assumes the individual to be a net saver during the early stages of life, and dissevers during retirement as Haron and Wan Azmi (2006) put it, the cornerstone of the life-cycle hypothesis is age related consumer heterogeneity. According to the predictions of the this model of savings, the savings curve takes a hump-shaped pattern which peaks in the middle ages of one life, with low savings during the young and old ages.

\section{The Permanent-Income Hypothesis of Savings:-}

The Permanent-Income Hypothesis was first propounded by Economist Milton Friedman in his treatise "A theory of consumption" in 1957 (Friedman, 1957). This model abstracted from retirement saving decisions. This theory distinguishes between permanent and temporary income. Income is argued by this model to consist of the permanent (anticipated and planned) component which is the expected long-term average income, and the temporary (transitory or windfall gain or unexpected) component (Abdelhafidh, 2013). According to the permanent-income hypothesis, consumption at a particular point in time is dependent on not only on one's current income but also on their expected future income (permanent income). The theory postulates that a consumer will save only if he expects that his long-term average income (permanent income) will be less than his current income (Arestis \& Demetriades, 1997).

\section{The Buffer-Stock Theory of Savings:-}

According to Baron (1997), this theory of saving is usually termed as the precautionary savings model. It argues that consumers are impatient and prudent in the face of unpredictable income fluctuations. The buffer-stock theory assumes consumers to be impatient because they resort to borrowing against future income in order to meet (finance) current consumptions if income were certain, and also as prudent because they have precautionary motives (Deaton, 1991; Christopher, 1992). Diamond (1985) says that in order to avoid or avert the dangers associated with future fluctuations in income, and also retain a smooth consumption pattern, individuals are forced to set aside some precautionary reserves by way of reducing current consumption in order to save against the contingent occurrences. Therefore, one would expect savings rate to be pro-cyclical, with individuals saving more when incomes are higher, in order to smoothen consumption in bad times (Agu \& Chukwu, 2008).

\section{Theory of imperfect/asymmetric information:-}

Markets are imperfect, according to this paradigm, because the ultimate parties who operate in the markets have insufficient information to conclude a transaction by themselves. Thus, to summarize, according to the modern theory of financial intermediation, financial intermediaries are active because market imperfections prevent savers and investors from trading directly with each other in an optimal way (Ange, 2008). The most important market imperfections are the informational asymmetries between savers and investors (Levin, 1997).

Financial intermediaries, banks specifically, fill as agents and as delegated monitors Information gaps between ultimate savers and investors. This is because they have a comparative informational advantage over ultimate savers and investors. They screen and monitor investors on behalf of savers. This is their basic function, which justifies the transaction costs they charge to parties. They also bridge the maturity mismatch between savers and investors and facilitate payments between economic parties by providing a payment, settlement and clearing system. Consequently, they engage in qualitative asset transformation activities. To ensure the sustainability of financial 
Intermediation, safety and soundness regulation has to be put in place. Regulation also provides the basis for the intermediaries to enact in the production of their monetary services.

\section{Modern Portfolio Theory:-}

Markowitz (1952) created a way to mathematically match an investor's risk tolerance and reward expectations to create an ideal investment portfolio. Modern portfolio theory is a theory on how risk averse-investors can construct portfolios to optimize or maximize expected return based on a given level of market risk, emphasizing that risk is an inherent part of higher reward. Portfolio theory sometimes called modern portfolio theory seeks to maximize returns while minimizing risk through the creation of portfolios that include investments that are not positively correlated with one another. In effect it seeks to assure that investments held in an account do not all move in a similar pattern. The overall effect of this diversification is to minimize volatility in return (Demirguc-Kunt \& Maksimovic, 2005).

\section{A Bird in Hand Theory:-}

Individual savers are unlikely to have the time or capacity to collect, process and compare information on many different enterprises, managers and market conditions before choosing where to invest. This can be explained well by this theory, which Al-Malkawi (2007) asserts that in a world of uncertainty and information asymmetry, dividends are valued differently from retained earnings (capital gains): "A bird in hand dividend is worth two in the bush (capital gains)". Owing to the uncertainty of future cash flow, investors will often tend to prefer dividends to retained earnings. Though this argument has been widely criticized and has not received strong empirical support has been supported by Gordon and Shapiro (1956), litner (1962) and Walter (1963). Thus high information costs may prevent capital from flowing to its highest value use. In addition, they will be less keen to invest in activities about which they have little information. So the creation of financial intermediaries such as banks and fund managers, who will collect this information on behalf of many investors, and share the costs of doing so between them, will improve resource allocation and increase investment (though in developing countries, financial institutions may have only limited information on investment opportunities, as much of the economy is informal). These intermediaries can facilitate selection between projects on the basis of informed judgments about expected returns, thus weeding out the weakest projects and ensuring that capital is allocated optimally (Greenwood \& Jovanovic, 1990). They may also increase the rate of technological progress by identifying and thus allocating capital towards those innovations with the best chances of succeeding (King \& Levine, 1993).

\section{Empirical review:-}

Greenwood and Jovanovic (1990) provide a theoretical analysis of ways in which financial intermediation can enhance productivity and growth by allocating efficiently funds in investment projects with high rates of return. Bencivenga and Smith (1991) suggest that financial intermediaries contribute to the efficient allocation of funds by increasing liquidity and diversifying risk, which in turn influences productivity growth. They acknowledge that regulatory measures such as interest rate ceilings can inhibit this process, particularly in developing nations. Recent studies focus on the mechanisms that improve productivity to analyse the financial development-economic growth link. Benhabib and Spiegel (1994) found that financial development enhances growth through greater TFP and capital accumulation. Beck and Levine (2002) employ a cross-country panel data to test the relationship between financial structure, industry growth, and new establishment formation. They find that an efficient legal system and financial development are both strong determinants of industry growth, new establishment formation and efficient capital allocation.

Less attention has been given, however, to the sources of growth in order to identify the exact mechanisms through which financial development influences economic growth (Rioja and Valev 2004). Jorgenson (2005) suggests that physical accumulation of capital does not necessarily produce long-run economic growth. Therefore, more recent studies attempt to explain the mechanism through which financial deepening impacts economic growth. As Levine (2004) puts it that if finance is to explain economic growth, we need theories that describe how financial development influences resource allocation decisions in ways that foster productivity growth. Some authors focused on how financial development affects economic growth through increasing productivity (Levine, Loayza, and Beck 2000; Arestis, Demetriades, and Fattouh 2003; Arestis, Chortareas, and Desli 2006). Fisman and Love (2003) test how financial deepening affects productivity growth. They found that in the long-run more financially developed countries allocate a higher share of resources towards sectors that rely primarily on external finance. These industries which depend on external financing are most likely to invest in R\&D and technology, and access to increased credit may stimulate greater productivity growth. Hartmann et al. (2007) show that financial deepening in Eastern European countries has led to faster capital reallocation; they conclude that deeper credit markets enhance 
capital reallocation by contributing to an increase in economic productivity growth. Lower TFP has been explained in developing countries by misallocation of resources across productive units. Thus, the presence of financial frictions increases the misallocation of resources (Chortareas et al., 2008). Contrastingly, as the financial system develops, information and transaction costs associated with capital reallocation decrease while TFP increases (Hsieh \& Klenow 2007; Restuccia \& Rogerson 2007).

In the literature, bank profitability is usually expressed as a function of internal and external determinants. The internal determinants could be termed micro or bank-specific determinants of performance. The external determinants are variables that are not related to bank management but reflect the economic and legal environment that affects the operation and performance of financial institutions (Athanasoglou et al, 2008). The research undertaken has focused on profitability analysis of either cross-country or individual countries' banking systems. The first group of studies includes Short (1979), Bourke (1989), Molyneux \& Thornton (1992) \& Demirguc-Kunt \& Huizinga (2000).

Another study in this group is Bikker and $\mathrm{Hu}$ (2002), though it is different in scope; its emphasis is on the bank profitability-business cycle relationship. Studies in the second group mainly concern the banking system in the US, Berger et al. (1987) or the emerging market economies Barajas et al. (1999). All of the above studies examine combinations of internal and external determinants of bank profitability. The empirical results vary significantly, since both datasets and environments differ. There exist, however, some common elements that allow a further categorization of the determinants. Studies dealing with internal determinants employ variables such as size, capital, risk management and expenses management. Size is introduced to account for existing economies or diseconomies of scale in the market. Smirlock (1985) finds a positive and significant relationship between size and bank profitability. Demirguc-Kunt and Huizinga (2000) suggest that the extent to which various financial, legal and other factors (e.g. corruption) affect bank profitability is closely linked to firm size. In addition, as Short (1979) argues, size is closely related to the capital adequacy of a bank since relatively large banks tend to raise less expensive capital and, hence, appear more profitable. Using similar arguments, Bikker and Hu (2002) and Goddard et al., (2004), among others, link bank size especially in the case of small to medium to capital and in further to profitability. However, many other researchers suggest that little cost saving can be achieved by increasing the size of a banking firm (Berger et al., 1987). The need for risk management in the banking sector is inherent in the nature of the banking business (Athanasoglou et al., 2008). Further, poor asset quality and low levels of liquidity are the two major causes of bank failures. During periods of increased uncertainty, financial institutions may decide to diversify their portfolios and/or raise their liquid holdings in order to reduce their risk. In this respect, risk can be divided into credit and liquidity risk. Molyneux and Thornton (1992), among others, find a negative and significant relationship between the level of liquidity and profitability. In contrast, Bourke (1989) reports an opposite result; while the effect of credit risk on profitability appears clearly negative (Miller \& Noulas, 1997).

Athanasoglou et al. (2008) explained this result by taking into account the fact that the more financial institutions are exposed to high-risk loans, the higher is the accumulation of unpaid loans, implying that these loan losses have produced lower returns to many commercial banks. Bank expenses are also a very important determinant of profitability, closely related to the notion of efficient management. There has been an extensive literature based on the idea that an expenses-related variable should be included in a profit function. For example, Bourke (1989) and Molyneux and Thornton (1992) find a positive relationship between better-quality management and profitability. Turning to the external determinants of bank profitability, it should be noted that we can further distinguish between control variables, such as inflation, interest rates and cyclical output, and variables that represent market characteristics. The latter refer to market concentration, industry size and ownership status. A whole new trend about structural effects on bank profitability started with the application of the market-power (MP) and the efficientstructure (ES) hypotheses. The MP hypothesis, which is sometimes also referred to as the structure-conductperformance (SCP) hypothesis, asserts that increased market power yields monopoly profits. A special case of the MP hypothesis is the relative-market-power (RMP) hypothesis, which suggests that only firms with large market shares and well-differentiated products are able to exercise market power and earn non competitive profits. Likewise, the $X$-efficiency version of the ES (ESX) hypothesis suggests that increased managerial and scale efficiency leads to higher concentration and, hence, higher profits. Studies, such as those by Smirlock (1985) and Berger (1995a) investigated the profit-structure relationship in banking, providing tests of the aforementioned two hypotheses. To some extent the RMP hypothesis is verified, since there is evidence that superior management and increased market share (especially in the case of small- to medium-sized banks) raise profits. 
In contrast, weak evidence is found for the ESX hypothesis. According to Berger (1995a), managerial efficiency not only raises profits, but may lead to market share gains and, hence, increased concentration, so that the finding of a positive relationship between concentration and profits may be a spurious result due to correlations with other variables. Thus, controlling for the other factors, the role of concentration should be negligible. Other researchers (Bourke, 1989; Molyneux and Thornton, 1992) argue instead that increased concentration is not the result of managerial efficiency, but rather reflects increasing deviations from competitive market structures, which lead to monopolistic profits. Consequently, concentration should be related to bank profitability. A rather interesting issue is whether the ownership status of a bank is related to its profitability. However, little evidence is found to support the theory that privately-owned institutions will return relatively higher economic profits (Short, 1979). In contrast, Bourke (1989) and Molyneux \& Thornton (1992) report that ownership status is irrelevant for explaining profitability.

The last group of profitability determinants deals with macroeconomic control variables. The variables normally used are the inflation rate, the long-term interest rate and/or the Average Payment Period of money supply. Revell (1979) introduces the issue of the relationship between bank profitability and inflation. He notes that the effect of inflation on bank profitability depends on whether banks' wages and other operating expenses increase at a faster rate than inflation. The question is how mature an economy is so that future inflation can be accurately forecasted and thus banks can accordingly manage their operating costs. In this vein, Perry (1992) states that the extent to which inflation affects bank profitability depends on whether inflation expectations are fully anticipated. An inflation rate fully anticipated by the bank's management implies that banks can appropriately adjust interest rates in order to increase their revenues faster than their costs and thus acquire higher economic profits. Most studies (Bourke, 1989; Molyneux and Thornton, 1992) have shown a positive relationship between either inflation or longterm interest rate and profitability as a measure of financial performance.

Recently, Demirguc-Kunt and Huizinga (2000) and Bikker and Hu (2002) attempted to identify possible cyclical movements in bank profitability, the extent to which bank profits are correlated with the business cycle. Their findings suggest that such correlation exists, although the variables used were not direct measures of the business cycle. Overall, but the effect of the macroeconomic environment is not adequately dealt with. The time dimension of the panels used in empirical studies is usually too small to capture the effect of control variables related to the macroeconomic environment (in particular the business cycle variable). Finally, sometimes there is an overlap between variables in the sense that some of them essentially proxy the same profitability determinant. It follows that studies concerning the profitability analysis of the banking sector should address the above issues more satisfactorily, in order to allow a better insight into the factors affecting profitability.

Liquidity is another factor that determines the level of bank performance. Liquidity refers to the ability of the bank to fulfill its obligations, mainly of depositors. According to Dang (2011) adequate level of liquidity is positively related with bank profitability. The most common financial ratios that reflect the liquidity position of a bank according to the above author are customer deposit to total asset and total loan to customer deposits. Other scholars use different financial ratio to measure liquidity. For instance Ilhomovich (2009) used cash to deposit ratio to measure the liquidity level of banks in Malaysia. However, the study conducted in China and Malaysia found that liquidity level of banks has no relationship with the performances of banks (Said and Tumin, 2011). 


\section{Conceptual Framework:-}

Independent Variable

\section{Dependent Variable}
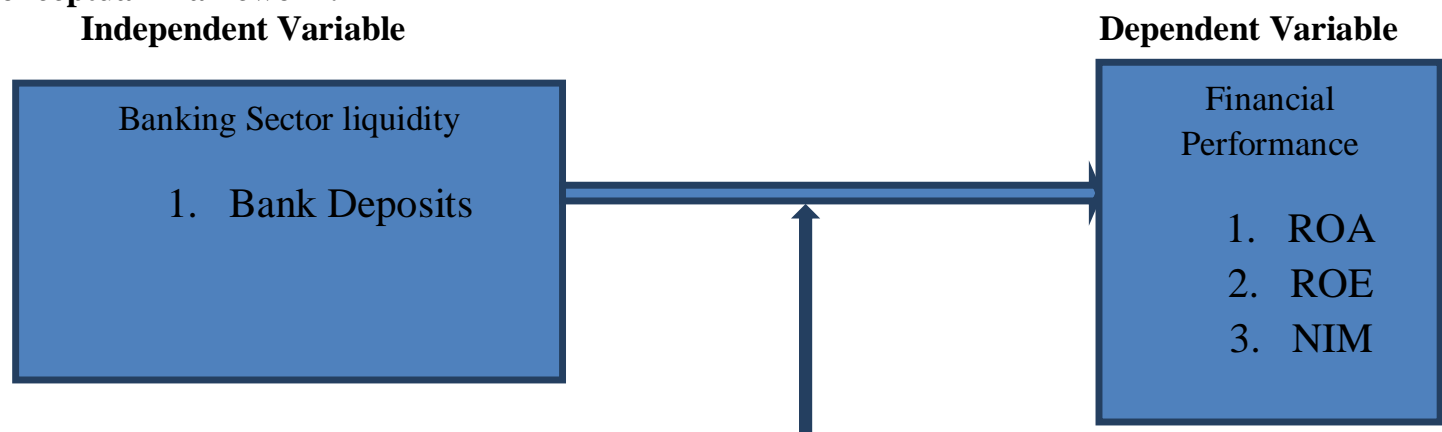

\section{Methodology:-}

\section{Moderating Variable}

The target population for this study was at institutional level where the study targeted all the 12 licensed commercial banks in Rwanda and in operation in Rwanda as at 31st December, 2015 (BNR, 2015). The entire target population constitutes of twelve (12), but only six (6) were purposively chosen since they had been licensed by National Bank of Rwanda from the year 2010. Therefore the study collected the secondary data from the sampled banks; ROA, ROE and NIM, bank deposits and Consumer Price Index. The secondary data was collected from the National Bank of Rwanda, National Institute of Statistics Rwanda, World Bank reports and annual reports of the banks from a period of 2010-2015.

The study used inferential statistics. In this paper, the multiple linear regression model that was adopted model is similar to that used by many of the studies done in the area of financial depth and financial performance (Ngumi, 2013; Ogilo, 2012; Ngigi, 2012; Chang, 2007; Waithaka \& Ngugi, 2013; Agostino \& Mazzuca, 2010). The general model to determine the influence of the banking sector liquidity on financial performance in commercial banks in Rwanda is shown below.

a. $Y_{t}=\alpha_{0}+\alpha_{1} b d_{t}+\alpha_{2} c p i_{t}+\varepsilon_{t}$

Where; Y= ROA (Return On Assets), ROE (Return on Equity) and NIM (Net Interest Margin)

$b d=$ Bank Deposits

$c p i=$ Consumer price Index

$\alpha_{0}=$ Intercept

$\alpha_{1}, \alpha_{2}=$ slopes

$\varepsilon=$ Error term

\section{Banking Sector Liquidity and ROA:-}

1. $R O A_{t}=\alpha_{0}+\alpha_{1} b d_{t}+\alpha_{2} c p i_{t}+\varepsilon_{t}$ 
The results of linear regression are presented in table 4.16 below. The model 1 transforms into $R O A_{t}=0.89+0.19 b d_{t}-0.015 c p i_{t}+\varepsilon_{t}$. The results indicate that banking sector liquidity has a positive significant influence on ROA. The results also conform to the descriptive results earlier discussed in this study. However, it is important to note that Bank deposits contributed the most positive influence on ROA. The analysis of the coefficient of determinant shows that banking sector liquidity is highly correlated to return on assets of commercial banks. As Keynes (1936) puts it, domestic savings creates a pool for liquidity in the banking sector which leads to banks having the power to offer private sector credits. This leads to banks achieving high Return on Asset. This results are also corroborated by Koasmidou (2008) while studying the determinants of banks profit in Greece during the period of EU, financial intergration and found that banking sector liquidity measured by savings had a positive and significant influence on profitability measured by ROA and ROE. From the model results, it can be seen that infaltion has a negative significant influence on ROA, this could be attributed to the fact that inflation increases the cost of living, "ceteris paribus". Consumers in an attempt to maintain the same standard of living will forego current savings and increase purchase of foreign goods and services; hence the possibility of a negative relationship commercial banks profitability. In other words, higher inflation would mean that people will need more money for expenses which will lead to cash withdrawals and a reduction in the level of deposits in general and a further reduction in credit to private sector in the long run. This view is further supported by the work of Singh and Kalirajan (2003) in the case of India and concluded that developing countries must work hard to reduce inflation as much as possible, in spite of the multiple objectives that distract their focus from targeting inflation.

Table 1:- Regression analysis of Banking Sector Liquidity and ROA in model 1

\begin{tabular}{|c|c|c|c|c|}
\hline \multicolumn{5}{|c|}{ Dependent Variable: ROA } \\
\hline \multicolumn{5}{|l|}{ Method: Least Squares } \\
\hline \multicolumn{5}{|c|}{ Date: 08/30/16 Time: 08:10 } \\
\hline \multicolumn{5}{|l|}{ Sample: 16} \\
\hline \multicolumn{5}{|c|}{ Included observations: 6} \\
\hline Variable & Coefficient & Std. Error & $\mathrm{t}$-Statistic & Prob. \\
\hline $\mathrm{C}$ & 0.898362 & 4.053209 & 0.221642 & 0.0052 \\
\hline $\mathrm{BD}$ & 0.195987 & 0.615043 & 0.318656 & 0.0002 \\
\hline CPI & -0.015652 & 0.279460 & -0.056009 & 0.0064 \\
\hline R-squared & 0.796539 & \multicolumn{2}{|c|}{ Mean dependent var } & 1.804391 \\
\hline Adjusted R-squared & -0.646922 & \multicolumn{2}{|l|}{ S.D. dependent var } & 0.472947 \\
\hline F-statistic & 0.214386 & \multicolumn{2}{|c|}{ Durbin-Watson stat } & 1.567550 \\
\hline Prob(F-statistic) & 0.003461 & & & \\
\hline
\end{tabular}

\section{Goodness of Fit:-}

In order to test the research objectives using regression analysis in the model equation 1, the researcher analyzed the goodness of fit of the regression line using the correlation coefficient $\left(R^{2}\right)$ which is equal to $79 \%$ from table 4.16 above (model summary). This means that $79 \%$ of variation in the dependent variable $(R O A)$ can be explained jointly by the independent variables $(b d, c p i)$ with only $21 \%$ of the variation in dependent variable $(R O A)$ can be explained by the error-term $(\varepsilon)$ or other variables other than $(b d, c p i)$. Therefore, from the analysis, the regression line of the model is strongly fitted to the data.

\section{Individual Significance:-}

To test if each and every independent variable in model 1 is individually significant in influencing the dependent variable $(R O A)$, the researcher considered the probability of $t$-statistics from table 1 above. This led to the formation of the hypothesis for each Individual variable's as follows:

\section{Significance of Bank Deposits $(b d)$ on Return on Asset $(R O A)$}

$$
\begin{aligned}
& H_{0}: \alpha_{1}=0 \text { if the probability of } t \text {-statistics is }>5 \% \\
& H_{1}: \alpha_{1} \neq 0 \text { if the probability of } t \text {-statistics is }<5 \%
\end{aligned}
$$


From the above table 1 , the probability of the $t$-statistics is equal to $0.02 \%$ which is less than $5 \%$, therefore the researcher rejected the null hypothesis and accepted the alternative hypothesis which means that the Independent Variable $(b d)$ significantly influences the Dependent Variable $(R O A)$. However, the direction of the influence can't be identified at this point, because the alternative hypothesis only shows the evidence of a relationship between the Dependent Variable and the Independent Variable.

$$
\begin{aligned}
& \text { Significance of Consumer Price Index }(c p i) \text { on Return on Asset }(R O A) \\
& H_{0}: \alpha_{1}=0 \text { if the probability of } t \text {-statistics is }>5 \% \\
& H_{1}: \alpha_{1} \neq 0 \text { if the probability of } t \text {-statistics is }<5 \%
\end{aligned}
$$

From the above table 1 , the probability of the $t$-statistics is equal to $0.6 \%$ which is less than $5 \%$, therefore the researcher rejected the null hypothesis and accepted the alternative hypothesis which means that the Independent Variable $(c p i)$ significantly influences the Dependent Variable $(R O A)$. However, the direction of the influence can't be identified at this point, because the alternative hypothesis only shows the evidence of a relationship between the Dependent Variable and the Independent Variable.

\section{Joint Significance:-}

To measure the joint significance between the Independent Variables $(b d, c p i)$ and the dependent variable $(R O A)$, the researcher considered the value of probability $F$-statistics (ANOVA) from table 1 above. This lead to the formation of the hypothesis bellow:

$$
\begin{aligned}
& H_{1}: \alpha_{1}=\alpha_{2}=\alpha_{3}=0 \text { if the probability of } F \text {-statistics is }>5 \% \\
& H_{1}: \alpha_{1} \neq \alpha_{2} \neq \alpha_{3} \neq 0 \text { if the probability of } F \text {-statistics is }<5 \%
\end{aligned}
$$

Since the probability of the $F$-statistics from table 4.16 above is equal to $0.03 \%$, which is less than $5 \%$, the researcher rejected the null hypothesis and failed to reject the alternative hypothesis meaning that all the Independent Variables $(b d, c p i)$ have significant joint effect on the Dependent Variable $(R O A)$.

\section{Normality in the residuals in model 1:-}

To test for normality in the population residuals, the study used Jaque-Bera test whose results are shown in figure 1 below. 


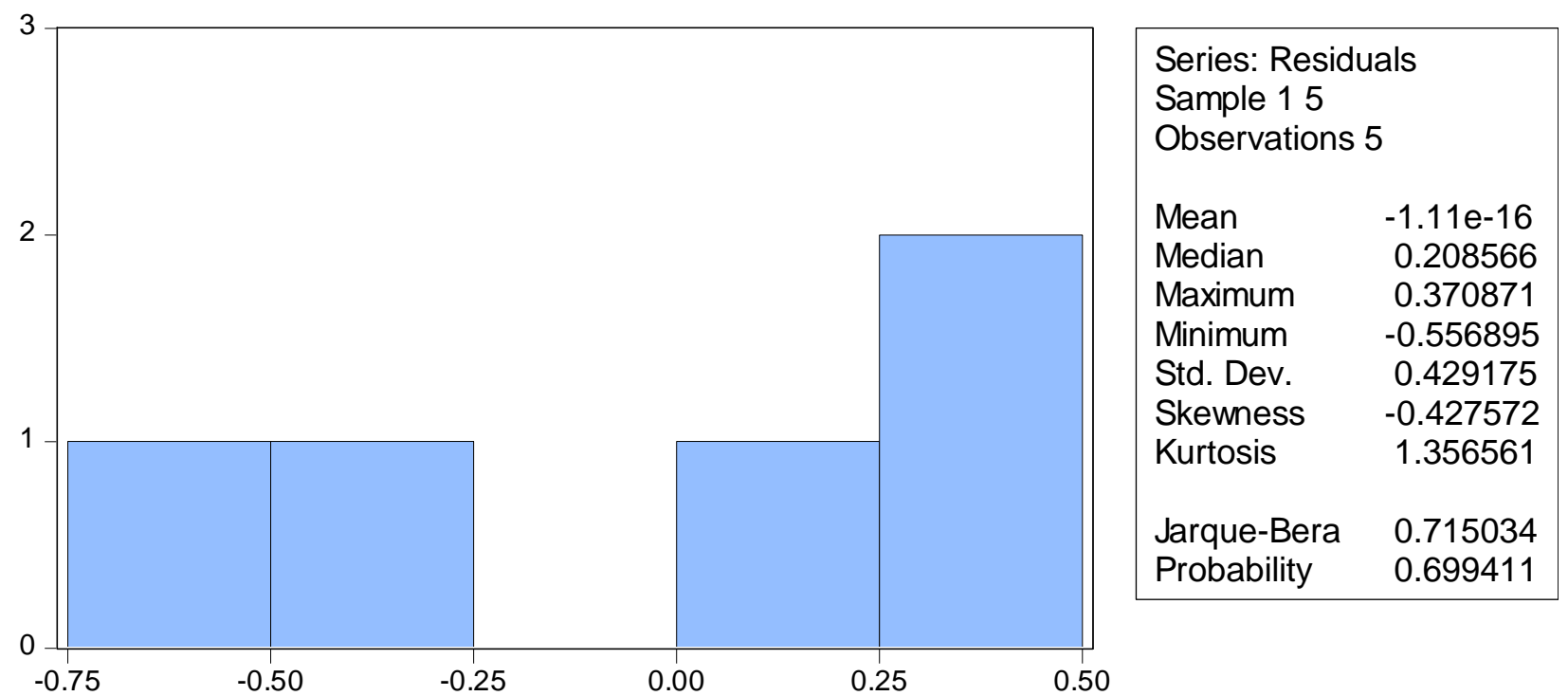

Figure 1:- Histogram-Normality Test for Normality of the Residuals in model 1.

To analyze the results of Jarque-Bera test in figure 1 above, the researcher set the following hypothesis;

$$
\begin{aligned}
& H_{0} \text { : Residuals are normally distributed if probability of Jarque-Bera statistics }>5 \% \\
& H_{1} \text { : Residuals are not normally distributed if probability of Jarque-Bera statistics }<5 \%
\end{aligned}
$$

The probability of Jarque Bera statistics from the figure 1 above is $69 \%$ which is more than $5 \%$, hence the researcher failed to reject the null hypothesis implying that the residuals are Normally distributed.

\section{Banking Sector Liquidity and ROE:-}

2. $R O E_{t}=\alpha_{0}+\alpha_{1} b d_{t}+\alpha_{2}$ cpi $_{t}+\varepsilon_{t}$

Table 2 contains result of model 2 above that can be further written as $R O E_{t}=-9.10+3.2 b d_{t}+1.2 c p i_{t}+\varepsilon_{t}$. After taking care of the assumptions of the linear regression model, the results indicate that bank deposits have a positive significant influence on return on equity of commercial banks in Rwanda. It is also evident that comparatively, inflation plays a less significant role in influencing the ROE. The evidence of a strong positive correlation between banking sector liquidity and ROE, shows the strength of the relation ship between the variables. It is reiterated that banks provide various services to sectors of the economy, like liquidity services, information, maturity intermediation, transaction cost, credit allocation, payment services, and money supply services, among others (Elsevier, 2014). The size of the local economy and prevailing legal restrictions as well as consumers propensity to save, coupled with other financial variables have an important influence on the growth of deposits with banks. With competition intensified through the process of financial liberalization, banks are being compelled to compete for deposits in various forms which further contribute positively to ROE (Haron and Wan Azmi, 2006).

\begin{tabular}{|c|c|c|c|c|}
\hline \multicolumn{3}{|c|}{ Dependent Variable: ROE } & & \\
\hline \multicolumn{3}{|l|}{ Method: Least Squares } & & \\
\hline \multicolumn{3}{|c|}{ Date: $08 / 30 / 16$ Time: $08: 30$} & & \\
\hline \multicolumn{3}{|l|}{ Sample: 16} & & \\
\hline \multicolumn{5}{|l|}{ Included observations: 6} \\
\hline Variable & Coefficient & Std. Error & t-Statistic & Prob. \\
\hline $\mathrm{C}$ & -9.101396 & 19.22964 & -0.473300 & 0.6826 \\
\hline $\mathrm{BD}$ & 3.251395 & 2.917950 & 1.114274 & 0.0381 \\
\hline $\mathrm{CPI}$ & 1.291349 & 1.325840 & 0.973986 & 0.0028 \\
\hline
\end{tabular}

Table 2:- Regression analysis of Banking sector Liquidity and ROE in model 2. 


\begin{tabular}{|l|r|l|l|}
\hline R-squared & 0.984568 & Mean dependent var & 12.28200 \\
\hline Adjusted R-squared & -0.230864 & S.D. dependent var & 2.595471 \\
\hline F-statistic & 0.624876 & Durbin-Watson stat & 1.479006 \\
\hline Prob(F-statistic) & 0.015432 & & \\
\hline
\end{tabular}

\section{Goodness of Fit:-}

In order to test the research objectives using regression analysis in the model equation 2, the researcher analyzed the goodness of fit of the regression line using the correlation coefficient $\left(R^{2}\right)$ which is equal to $98.4 \%$ from table 2 above (model summary). This means that $98.4 \%$ of variation in the dependent variable $(R O E)$ can be explained jointly by the independent variables $(b d, c p i)$ with only $1.6 \%$ of the variation in dependent variable $(R O E)$ can be explained by the error-term $(\varepsilon)$ or other variables other than $(b d, c p i)$. Therefore, from the analysis, the regression line of the model is strongly fitted to the data.

\section{Individual Significance:-}

To test if each and every independent variable in model 2 is individually significant in influencing the dependent variable $(R O E)$, the researcher considered the probability of $t$-statistics from table 2 above. This led to the formation of the hypothesis for each Individual variable's as follows:

\section{Significance of Bank Deposits $(b d)$ on Return on Equity $(R O E)$}

$$
\begin{aligned}
& H_{0}: \alpha_{1}=0 \text { if the probability of } t \text {-statistics is }>5 \% \\
& H_{1}: \alpha_{1} \neq 0 \text { if the probability of } t \text {-statistics is }<5 \%
\end{aligned}
$$

From the above table 2, the probability of the $t$-statistics is equal to $3.8 \%$ which is less than $5 \%$, therefore the researcher rejected the null hypothesis and accepted the alternative hypothesis which means that the Independent Variable $(b d)$ significantly influences the Dependent Variable $(R O E)$. However, the direction of the influence can't be identified at this point, because the alternative hypothesis only shows the evidence of a relationship between the Dependent Variable and the Independent Variable.

\section{Significance of Consumer Price Index $(c p i)$ on Return on Equity $(R O E)$

$$
\begin{aligned}
& H_{0}: \alpha_{1}=0 \text { if the probability of } t \text {-statistics is }>5 \% \\
& H_{1}: \alpha_{1} \neq 0 \text { if the probability of } t \text {-statistics is }<5 \%
\end{aligned}
$$

From the above table 2, the probability of the $t$-statistics is equal to $0.2 \%$ which is less than $5 \%$, therefore the researcher rejected the null hypothesis and accepted the alternative hypothesis which means that the Independent Variable $(c p i)$ significantly influences the Dependent Variable $(R O E)$. However, the direction of the influence can't be identified at this point, because the alternative hypothesis only shows the evidence of a relationship between the Dependent Variable and the Independent Variable.

\section{Joint Significance:-}

To measure the joint significance between the Independent Variables $(b d, c p i)$ and the dependent variable $(R O E)$, the researcher considered the value of probability $F$-statistics (ANOVA) from table 2 above. This lead to the formation of the hypothesis bellow:

$$
\begin{aligned}
& H_{1}: \alpha_{1}=\alpha_{2}=0 \text { if the probability of } F-\text { statistics is }>5 \% \\
& H_{1}: \alpha_{1} \neq \alpha_{2} \neq 0 \text { if the probability of } F \text {-statistics is }<5 \%
\end{aligned}
$$


Since the probability of the $F$-statistics from table 2 above is equal to $0.2 \%$, which is less than $5 \%$, the researcher rejected the null hypothesis and failed to reject the alternative hypothesis meaning that all the Independent Variables $(b d, c p i)$ have significant joint effect on the Dependent Variable $(R O E)$.

\section{Normality in the residuals in model 2:-}

To test for normality in the population residuals, the study used Jaque-Bera test whose results are shown in figure 2 below.

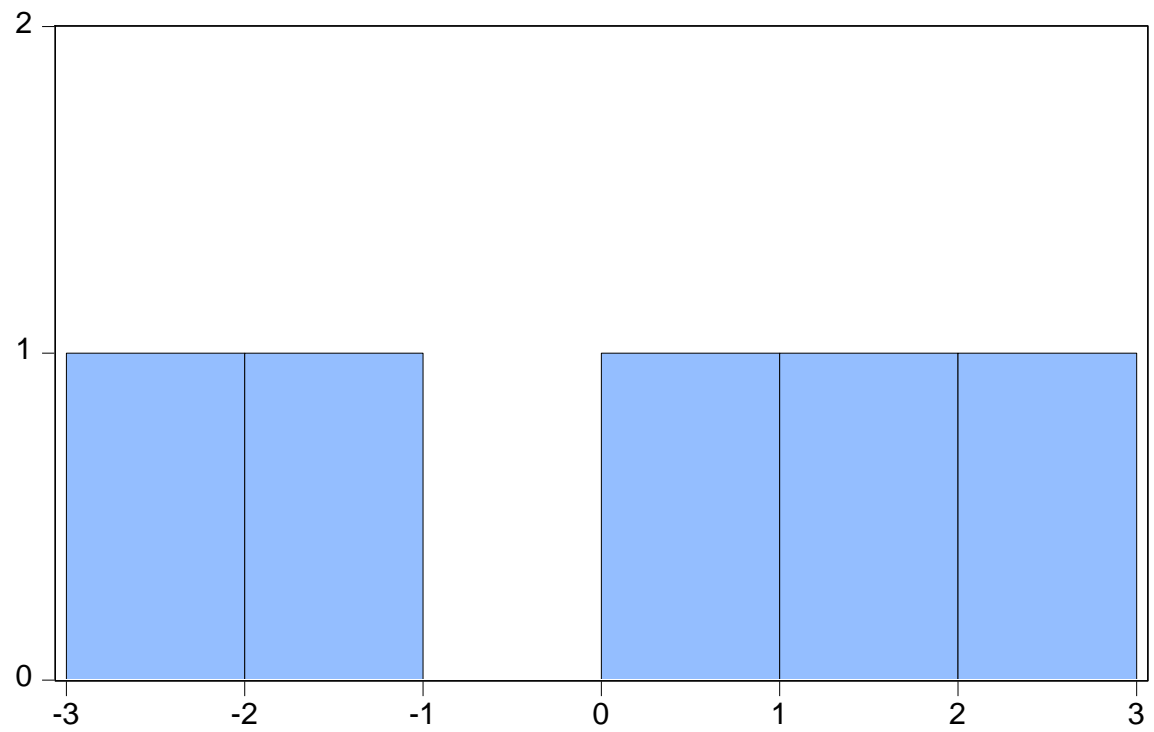

\begin{tabular}{|lr|}
\hline \multicolumn{2}{|l|}{ Series: Residuals } \\
Sample 15 \\
Observations 5 \\
Mean & $2.00 \mathrm{e}-15$ \\
Median & 0.809968 \\
Maximum & 2.048692 \\
Minimum & -2.631874 \\
Std. Dev. & 2.036133 \\
Skewness & -0.355236 \\
Kurtosis & 1.414660 \\
& \\
Jarque-Bera & 0.628765 \\
Probability & 0.730240 \\
\hline
\end{tabular}

Figure 2:- Histogram-Normality Test for Normality of the Residuals in model 4.5

To analyze the results of Jarque-Bera test in figure 2 above, the researcher set the following hypothesis;

$$
\begin{aligned}
& H_{0} \text { : Residuals are normally distributed if probability of Jarque-Bera statistics }>5 \% \\
& H_{1} \text { : Residuals are not normally distributed if probability of Jarque-Bera statistics }<5 \%
\end{aligned}
$$

The probability of Jarque Bera statistics from the figure 2 above is $73 \%$ which is more than $5 \%$, hence the researcher failed to reject the null hypothesis implying that the residuals are Normally distributed.

\section{Banking Sector Liquidity and NIM:-}

3. $\operatorname{NIM}_{t}=\alpha_{0}+\alpha_{1} b d_{t}+\alpha_{2} c p i_{t}+\varepsilon_{t}$

The correlation coefficient in table 3 shows that $87 \%$ of the NIM is influenced by the dependent variables bank deposits and moderating variable consumer price index and that only $13 \%$ is explained by the error term. As its well known among statisticians, correlation only shows the strength of the relationship but not the direction therefore $87 \%$ shows a strong relationship between banking sector liquidity and NIM. Further, to analyse the direction of the relationship the regression results of model 3 is required. $N I M_{t}=11.2-0.01 b d_{t}-0.3 c p i_{t}+\varepsilon_{t}$ Indicate that bank deposits have a negative significant influence on NIM of commercial banks in Rwanda. NIM measures the cost of intermediation of commercial banks; therefore if the bank deposits increase, it will have a negative influence shall the interest on credit to private sector (loans) become less than the interest paid to the depositors. It is therefore clear that commercial banks in Rwanda do not prefer having more deposits than they can make profit of. This results are corroborated by Koasmidou (2008) while studying the determinants of banks profit in Greece during the period of EU, financial intergration and found that banking sector liquidity had a positive and significant influence on performnace measured by ROA and ROE but a negative infliuence on NIM. Another study by Rose et al., (2006) which states that the net interest margin (NIM) measures how large the spread between interest revenues and interest costs that management has been able to achieve by close control over earning assets and the pursuit of the cheapest sources of funding, found a negative correlation between bank deposits and NIM which is inline with this study results. 
Table 3:- Regression analysis of Banking Sector Liquidity and NIM in model 3.

\begin{tabular}{|c|c|c|c|c|}
\hline \multicolumn{3}{|c|}{ Dependent Variable: NIM } & & \\
\hline \multicolumn{3}{|c|}{ Method: Least Squares } & & \\
\hline \multicolumn{3}{|c|}{ Date: 08/30/16 Time: 08:38 } & & \\
\hline \multicolumn{3}{|l|}{ Sample: 16} & & \\
\hline \multicolumn{5}{|c|}{ Included observations: 6} \\
\hline Variable & Coefficient & Std. Error & t-Statistic & Prob. \\
\hline $\mathrm{C}$ & 11.29156 & 2.320875 & 4.865218 & 0.0397 \\
\hline $\mathrm{BD}$ & -0.016951 & 0.352175 & -0.048132 & 0.0260 \\
\hline CPI & -0.347928 & 0.160019 & -2.174290 & 0.0117 \\
\hline R-squared & 0.879162 & \multicolumn{2}{|c|}{ Mean dependent var } & 9.782646 \\
\hline Adjusted R-squared & 0.758323 & \multicolumn{2}{|l|}{ S.D. dependent var } & 0.706943 \\
\hline F-statistic & 7.275524 & \multicolumn{2}{|c|}{ Durbin-Watson stat } & 2.576929 \\
\hline Prob(F-statistic) & 0.012083 & & & \\
\hline
\end{tabular}

\section{Goodness of Fi:-t}

In order to test the research objectives using regression analysis in the model equation 3, the researcher analyzed the goodness of fit of the regression line using the correlation coefficient $\left(R^{2}\right)$ which is equal to $87.9 \%$ from table 3 above (model summary). This means that $87.9 \%$ of variation in the dependent variable $(N I M)$ can be explained jointly by the independent variables $(b d, c p i)$ with only $12.1 \%$ of the variation in dependent variable $(N I M)$ can be explained by the error-term $(\varepsilon)$ or other variables other than $(b d, c p i)$. Therefore, from the analysis, the regression line of the model is strongly fitted to the data.

Individual Significance:-

To test if each and every independent variable in model 3 is individually significant in influencing the dependent variable $(N I M)$, the researcher considered the probability of $t$-statistics from table 3 above. This led to the formation of the hypothesis for each Individual variable's as follows:

Significance of Bank Deposits $(b d)$ on Net Interest Margin (NIM)

$$
\begin{aligned}
& H_{0}: \beta_{1}=0 \text { if the probability of } t \text {-statistics is }>5 \% \\
& H_{1}: \beta_{1} \neq 0 \text { if the probability of } t \text {-statistics is }<5 \%
\end{aligned}
$$

From the above table 3 , the probability of the $t$-statistics is equal to $2.6 \%$ which is less than $5 \%$, therefore the researcher rejected the null hypothesis and accepted the alternative hypothesis which means that the Independent Variable $(b d)$ significantly influences the Dependent Variable $(N I M)$. However, the direction of the influence can't be identified at this point, because the alternative hypothesis only shows the evidence of a relationship between the Dependent Variable and the Independent Variable.

\section{Significance of Consumer Price Index $(c p i)$ on Net interest Margin (NIM)

$$
\begin{aligned}
& H_{0}: \alpha_{3}=0 \text { if the probability of } t \text {-statistics is }>5 \% \\
& H_{1}: \alpha_{3} \neq 0 \text { if the probability of } t \text {-statistics is }<5 \%
\end{aligned}
$$

From the above table 3 , the probability of the $t$-statistics is equal to $1.1 \%$ which is less than $5 \%$, therefore the researcher rejected the null hypothesis and accepted the alternative hypothesis which means that the Independent Variable $(c p i)$ significantly influences the Dependent Variable $(N I M)$. However, the direction of the influence can't be identified at this point, because the alternative hypothesis only shows the evidence of a relationship between the Dependent Variable and the Independent Variable. 


\section{Joint Significance:-}

To measure the joint significance between the Independent Variables $(b d, c p i)$ and the dependent variable (NIM), the researcher considered the value of probability $F$ - statistics (ANOVA) from table 3 above. This lead to the formation of the hypothesis bellow:

$$
\begin{aligned}
& H_{0}: \alpha_{1}=\alpha_{2}=\alpha_{3}=0 \text { if the probability of } F \text {-statistics is }>5 \% \\
& H_{0}: \alpha_{1} \neq \alpha_{2} \neq \alpha_{3} \neq 0 \text { if the probability of } F \text {-statistics is }<5 \%
\end{aligned}
$$

Since the probability of the $F$-statistics from table 4.18 above is equal to $1.2 \%$, which is less than $5 \%$, the researcher rejected the null hypothesis and failed to reject the alternative hypothesis meaning that all the Independent Variables $(b d, c p i)$ have significant joint effect on the Dependent Variable (NIM) .

\section{Normality test of the residuals in model 3:-}

To test for normality in the population residuals, the study used Jaque-Bera test whose results are shown in figure 3 below.

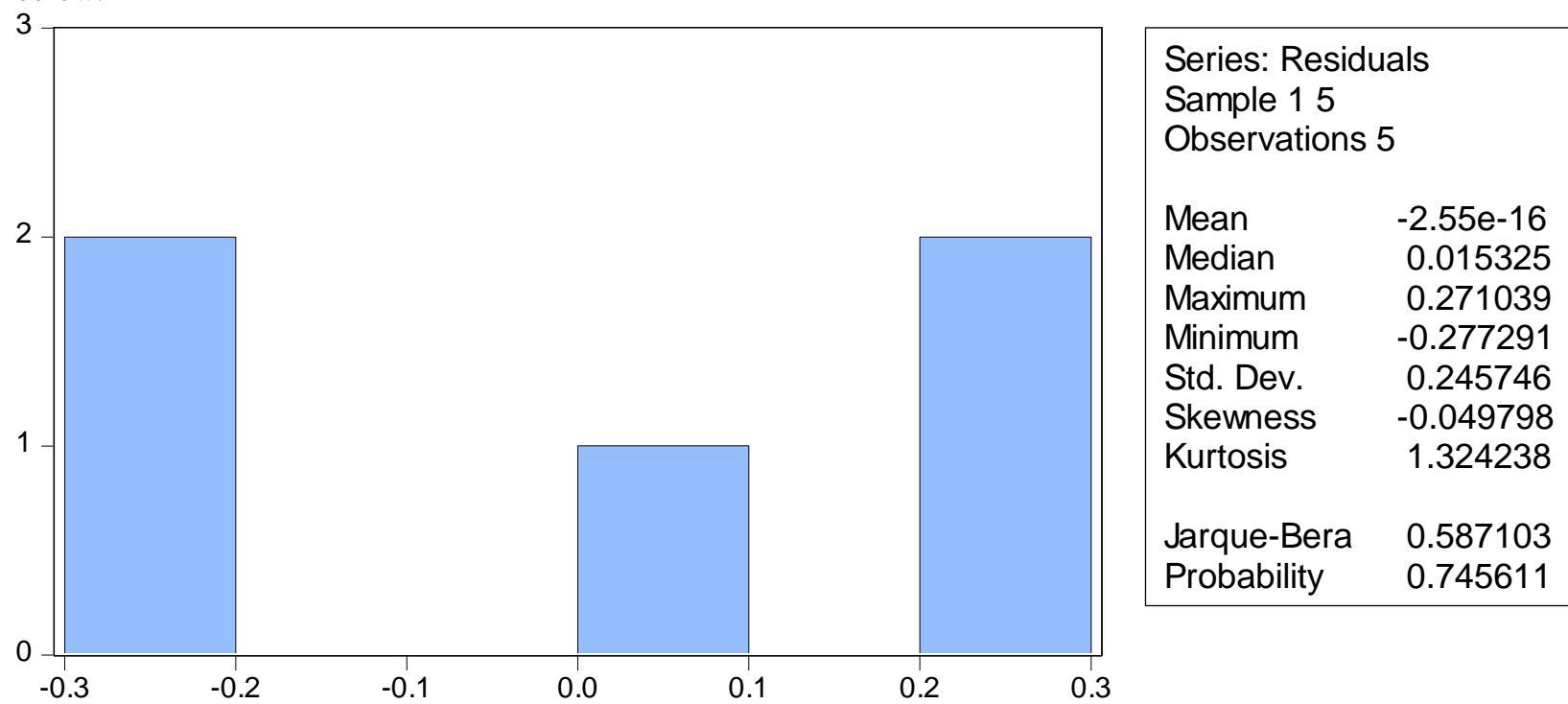

Figure 3:- Histogram-Normality Test for Normality of the Residuals in model 3

The results of Jarque-Bera test in figure 3 above, the researcher set the following hypothesis;

$$
\begin{aligned}
& H_{0} \text { : Residuals are normally distributed if probability of Jarque-Bera statistics }>5 \% \\
& H_{1} \text { : Residuals are not normally distributed if probability of Jarque-Bera statistics }<5 \%
\end{aligned}
$$

The probability of Jarque Bera statistics from the figure 3 above is $74 \%$ which is greater than $5 \%$, hence the researcher failed to reject the null hypothesis implying that the residuals are normally distributed.

\section{Conclusion:-}

From model 1 whose result is $R O A_{t}=0.89+0.19 b d_{t}-0.015 c p i_{t}+\varepsilon_{t}$ it can be seen that banking sector liquidity measured by bank deposits has a positive significant influence on return on assets, while any increase in inflation would further have a negative influence on ROA. When financial performance was measured by ROE in model $2 R O E_{t}=-9.10+3.2 b d_{t}+1.2 c p i_{t}+\varepsilon_{t}$, banking sector liquidity proxied by bank deposits again has a positive and significant influence on ROE but with inflation having a positive influence. However on model 3 $N I M_{t}=11.2-0.01 b d_{t}-0.3 c p i_{t}+\varepsilon_{t}$ when financial performance is measured by banks cost of operation Net Interest Margin (NIM), both bank deposits and consumer price index registered negative significant influence on the same. 
As Keynes (1936) supports the results of model 1, he puts it that, domestic savings creates a pool for liquidity in the banking sector which leads to banks having the power to offer private sector credits. This leads to banks achieving high Return on Asset. This results are also corroborated by Koasmidou (2008) while studying the determinants of banks profit in Greece during the period of EU, financial intergration and found that banking sector liquidity measured by savings had a positive and significant influence on profitability measured by ROA and ROE. From the model results, it can be seen that infaltion has a negative significant influence on ROA, this could be attributed to the fact that inflation increases the cost of living, "ceteris paribus". Consumers in an attempt to maintain the same standard of living will forego current savings and increase purchase of foreign goods and services; hence the possibility of a negative relationship commercial banks profitability. In other words, higher inflation would mean that people will need more money for expenses which will lead to cash withdrawals and a reduction in the level of deposits in general and a further reduction in credit to private sector in the long run. This view is further supported by the work of Singh and Kalirajan (2003) in the case of India and concluded that developing countries must work hard to reduce inflation as much as possible, in spite of the multiple objectives that distract their focus from targeting inflation.

The evidence of a strong positive correlation between banking sector liquidity and ROE in model 2, shows the strength of the relationship between the variables. It is reiterated that banks provide various services to sectors of the economy, like liquidity services, information, maturity intermediation, transaction cost, credit allocation, payment services, and money supply services, among others (Elsevier, 2014). The size of the local economy and prevailing legal restrictions as well as consumers propensity to save, coupled with other financial variables have an important influence on the growth of deposits with banks. With competition intensified through the process of financial liberalization, banks are being compelled to compete for deposits in various forms which further contribute positively to ROE (Haron \& Azmi, 2006).

The $3^{\text {rd }}$ model contains NIM which measures the cost of intermediation of commercial banks; therefore if the bank deposits increase, it will have a negative influence shall the interest on credit to private sector (loans) become less than the interest paid to the depositors. It is therefore clear that commercial banks in Rwanda do not prefer having more deposits than they can make profit of. This results are corroborated by Koasmidou (2008) while studying the determinants of banks profit in Greece during the period of EU, financial intergration and found that banking sector liquidity had a positive and significant influence on performnace measured by ROA and ROE but a negative infliuence on NIM. Another study by Rose et al., (2006) which states that the net interest margin (NIM) measures how large the spread between interest revenues and interest costs that management has been able to achieve by close control over earning assets and the pursuit of the cheapest sources of funding, found a negative correlation between bank deposits and NIM which is inline with this study results.

This study can conclude that banking sector liquidity has a positive significant influence on banking profitability measure by ROA and ROE but a negative significant influence on Cost of operation measured by NIM.

\section{Recommendation:-}

For commercial banks in Rwanda to improve their profitability, they should put in place measures to encourage bank deposits for example higher interest rates to encourage depositors. However to reduce the cost of operation, the study recommends that commercial banks in Rwanda need to reduce problem assets as high nonperforming loans dampen banks' potential lending capacity and, by extension, their ability to build up capital buffers. This study further recommends that commercial banks should do a lot of their own awareness, sensitization, education and training to increase the use of other financial innovations like ATM's, agency banking, internet banking and the use of credit cards to further promote mobilization of savings.

\section{References:-}

1. Aburime, U. (2005). Determinants of Bank Profitability: Company-Level Evidence from Nigeria. Nigeria: University of Nigeria, Enugu Campus.

2. Agu, C.C., \& Chukwu, J., O. (2008). Toda and Yamamoto causality tests between "bank based" financial deepening and economic growth in Nigeria. European Journal of Social Science, Vol. 7(2), pp.189-98.

3. Al-Malkawi, H., N. (2007). Determinant of Corporate Dividend Policy in Jordan, Journal of Economic and Administrative, Vol. 23, pp. 44-71. 
4. Arestis, P., \& Chortareas, G., \& Desli, E. (2006). Financial development and productive efficiency in OECD countries: An exploratory analysis. The Manchester School vol. 74(4): 417-40.

5. Arestis, P., \& Demetriades, P. (1997). Financial development and economic growth: assessing the evidence. Economic Journal Vol.107, pp. 783-799.

6. Arestis, P., \& Demetriades, P., \& Fattouh, B. (2003). Financial policies and the aggregate productivity of the capital stock. Eastern Economic Journal 29, no. 2: 217-42.

7. Beck, T., \& Levine, R. (2002). Industry Growth and Capital Allocation: Does having a market- $r$ bank-based system matter?, Journal of Financial Economics, Vol. 64, pp.147-180.

8. Beck, T., Demirguc-Kunt, A., \& Levine, R (2004). Finance, Inequality and Poverty: Cross-Country Evidence, World Bank Policy Research Working Paper 3338.

9. Beck, T., Levine, R., \& Loayza, N. (2000). Finance and the Sources of Growth, Journal of Financial Economics, Vol. 58(1\&2), pp. 261-300.

10. Bencivenga, V. R., \& Smith B. D. (1991). Financial Intermediation and Endogenous Growth, Review of Economic Studies, 58(2), pp. 195-209.

11. Berger, A.N., Hanweck, G.A., Humphrey, D.B., (1987). Competitive viability in banking: scale, scope and product mix economies. Journal of Monetary Economics 20, 501-520.

12. Bikker, J.A., \& Hu, H. (2002). Cyclical patterns in profits, provisioning and lending of banks and procyclicality of the new Basel capital requirements. BNL Quarterly Review vol. 221, 143-175.

13. Deaton, A., \& S., (1991). Saving and liquidity constraints. Econometrica, 59(5): 1221- 1248.

14. Demirguc-Kunt, A., \& Huizinga, H., (2000). Financial structure and bank profitability. Policy Research Working Paper Series 2430. The World Bank.

15. Demirguc-Kunt, A., and Maksimovic, V. (2002). Funding Growth in Bank-Based and Market-Based Financial Systems: Evidence from Firm Level Data, Journal of Financial Economics, Vol. 65, pp. 337- 63.

16. Diamond, D., W. (1984). Financial intermediation and delegated monitoring. Review of Economic Studies 51, no. 3: 393-414.

17. Diamond, D., W., \& Raghuram, A. (2000) A Theory of Bank Capital. The Journal of Finance. 52(6), 12-23.

18. Dillon, A., \& Morris, M. (1996). User acceptance of new information technology: theories and models. Annual Review of Information Science and Technology, Medford (NJ), 31, 3-32.

19. Ferguson, R., \& Hartmann, P., \& Portes, R. (2007). International Financial Stability, Geneva Reports on the World Economy, International Center for Monetary and Banking Studies and CEPR, Geneva.

20. Ferguson, R., \& Hartmann, P., \& Portes, R. (2007). International Financial Stability, Geneva Reports on the World Economy, International Center for Monetary and Banking Studies and CEPR, Geneva.

21. Fisman, R., \& Love. I. (2003). Trade Credit, financial intermediary development, and industry growth. Journal of Finance 58, no. 1: 353-74.

22. Friedman, M., (1957). A theory of the consumption function. General Series No. 63. National Bureau of Economic Research, Cambridge, Mass. Processed.

23. Greenwood, J., \& Jovanovic, B. (1990). Financial Development, Growth and the Distribution of Income", Journal of Political Economy, Vol. 98(5, Pt.1), pp.1076-1107.

24. Greenwood, J., \& Smith, B. (1997). Financial Markets in Development and the Development of Financial Markets, Journal of Political Economy, Vol. 98(5) pp. 1076-107.

25. Haron, S., \& N. Ahmad, (2000). The effects of conventional interest rates and rate of profit on funds deposited with islamic banking system in Malaysia. Intl. J. Islamic Financial Services, 1(4): 1-7.

26. Haron, S., \& Wan, A., W. (2006). Deposit determinants of commercial banks in Malaysia. Creating Dynamic Leaders. Working Paper Series No. 009, 20(2).

27. Ilhomovich, S., E. (2009). Factors affecting the performance of foreign banks in Malaysia. Malaysia: A thesis submitted to the fulfillment of the requirements for the degree Master of Science (Banking) College of Business (Finance and Banking.)

28. Keynes, J., M., (1936). The general theory of employment, interest, and money. Japan: Maruzen Co., Ltd.

29. Khrawish, H., A. (2011). Determinants of Commercial Banks Performance: Evidence from Jordan. International Research Journal of Finance and Economics. Zarqa University, 5(5), 19-45.

30. Kigabo.R., T., \& Okello, J., P., \& Mutuyimana J., P. (2015). Financial Development, Monetary policy and Economic Growth in Rwanda . BNR Economic Review, Vol. (7) pp. 79-99

31. King, R. G. \& Levine, R. (1993a). Financial Intermediation and Economic Development, in Financial Intermediation in the Construction of Europe, Eds. Colin Mayer and Xavier Vives. London: Centre for Economic Policy Research, pp.156-189 
32. King, R. G. \& Levine, R. (1993b). Finance and Growth: Schumpeter Might be Right, Quarterly Journal of Economics, Vol. 108(3), pp.717-38.

33. King, R. G. \& Levine, R (1993c). Finance, Entrepreneurship and Growth: Theory and Evidence, Journal of Monetary Economics, Kuznets; 1955, Economic Growth and Income Inequality. Vol. 32(3), pp.513-42

34. Levine, R. (1991). Stock markets, growth, and tax policy. Journal of Finance Vol. 46(4), pp. 1445-1465.

35. Levin, A., \& Lin, C.F. (1993). Unit root tests in panel data: asymptotic and finite sample properties. Mimeo (September). Vol.108 (1)

36. Levine, R. (1997). Financial Development and Economic Growth: Views and Agenda, Journal of Economic Literature, Vol. 32(2), 35, pp. 688-726.

37. Levine, R. (1998). Financial Development and Economic Growth; Views and Agenda, Journal of Economic Literature, Vol. 35(2), pp.31-77.

38. Levine, R. (2000). Bank-Based or Market-Based Financial Systems: Which is Better? mimeo, University of Minnesota, January.

39. Levine, R. (2004). Finance and growth: Theory and evidence. NBER Working Paper Series 10766, National Bureau of Economic Research, Cambridge, MA

40. Levine, R., \& Loayza, N., \& Beck, T. (2000). Financial intermediation and growth: Causality and causes. Journal of Monetary Economics 46, no. 1: 31-77.

41. Levine, R., Loayza, N., \& Beck, T. (2000). Financial Intermediation and Growth: Causality and Causes, Journal of Monetary Economics, Vol. 46(1), pp. 31-77.

42. Levine, R. (2005). Finance and Growth: Theory, Evidence, and Mechanisms, in P. Aghion and S. Durlauf (eds), The Handbook of Economic Growth, Amsterdam: North-Holland.

43. Markowitz, H. (1952). Portfolio selection, The Journal of Finance, Vol.7, pp. 77-91.

44. Miller, S.M., \& Noulas, A., G. (1997). Portfolio mix and large-bank profitability in the USA. Applied Economics. International journal of applied economics. Vol. 29, 505-512.

45. Modigliani, F., \& Brumberg., R. (1954). Utility analysis and the consumption function: An interpolation of the cross-section data, in post-Keynesian economics, (Eds). K. Kurihara. New Brunswick, NJ: Rutgers U. Press. pp: 388-436.

46. Molyneux, P., \& Thornton, J. (1992). Determinants of European bank profitability: a note. Journal of Banking and Finance 16, 1173-1178.

47. Nishat, M., \& Bilgrami, N. (1989). Determinants of growth of bank deposits in Pakistan. Giordano dell-amore foundation. Journal of economics and Development, 13(4): 391-400.

48. Okello, J., P., \& Kigabo, R., T., \& Kitambala, M. (2015). Banking Development and Economic Growth in Rwanda. African Journal of Business and Industry Vol. (1) pp.50-77

49. Panayiotis, P., \& Athanasoglou, (2006). Bank-specific, industry-specific and macroeconomic determinants of bank profitability. Journal of International Financial Markets, Institutes and Money 18 (2008) 121-136

50. Perry, P. (1992). Do banks gain or lose from inflation? Journal of Retail Banking 14, 25-30.

51. Piergiorgio, C. (2003). Social Research: Theory methods and techniques, Sage Publishers, London.

52. Revell, J., (1979). Inflation and financial institutions. Financial Times, London.

53. Said, R., M., \& Mohd, H., T. (2011) Performance and Financial Ratios of Commercial Banks in Malaysia and China.

54. Sanya, S., \& Gaertner, M. (2012). Assessing bank competition within the East African Community, IMF working paper, WP/12/32. (Washington DC: International Monetary Fund).

55. Saunders, M., \& Lewis, P., \& Thornhill, A. (2007). Research Methods for Business Students, (4 ${ }^{\text {th }}$ ed) Prentice Hall Financial Times, Harlow.

56. Schumpeter, J. A. (1912). Theorie der Wirtschaftlichen Entwicklung (The Theory of Economic Development), Leipzig: Dunker \& Humblot 1912; translated by Rredvers Opie. Cambridge Ma: Harvard U. Press, 1934.

57. Short, B.K., (1979). The relation between commercial bank profit rates and banking concentration in Canada, Western Europe and Japan. Journal of Banking and Finance 3, 209-219.

58. Smith, P. (1997). Model misspecification in data envelopment analysis. Annals of Operations Research 72, no. 1: $233-52$.

59. Todaro, M. P., \& Stephen C. S. (2003). Economic Development. $8^{\text {th }}$ ed. Addison Wesley. 